\title{
Effects of in feed removal of antimicrobials in comparison to other prophylactic alternatives in growing and finishing pigs
}

\author{
[Efeitos na remoção de antimicrobianos na ração em comparação a alternativas profiláticas \\ em suínos nas fases de crescimento e de terminação]

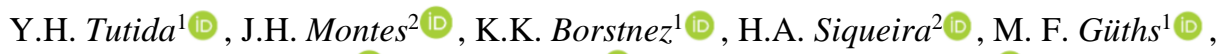

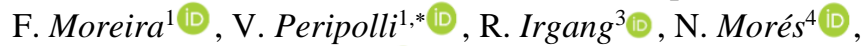 I. Bianchi ${ }^{1(D)}$, J.D. Kich ${ }^{1,4}$ (D) \\ ${ }^{1}$ Graduate, Instituto Federal Catarinense, Campus Araquari, Araquari, SC, Brasil \\ ${ }^{2}$ Instituto Federal Catarinense, Campus Araquari, Araquari, SC, Brasil \\ ${ }^{3}$ Universidade Federal de Santa Catarina, Florianópolis, SC, Brasil \\ ${ }^{4}$ Embrapa Suínos e Aves, 89715-899 Concórdia, SC, Brasil
}

\begin{abstract}
The utilization of antimicrobials in animal production, causes selection of resistant bacteria. The objective of this study was to compare the utilization of alternatives in association with preventive antibiotic therapy in swine feed during the growing and finishing phases. 1,045 animals were used from 60 to 190 days of age and were subjected to six treatments with 16 repetitions as follows: 1) antibiotic free; 2) antibiotics; 3) prebiotic; 4) probiotic; 5) essential oils; and 6) organic acid. Animals were weighted, and clinical history was recorded including mortality and diarrhea. At the abattoir, pneumonia index and gastric ulcers were investigated. The cost for each treatment was discussed. No difference between treatments were observed (P>0.05) regarding feed conversion rate $(2.64 \pm 0.03)$, overall average weight gain $(107.06 \pm 0.9 \mathrm{~kg})$, average daily weight gain $(856.49 \pm 7.7 \mathrm{~g})$ and carcass weight $(92.4 \pm 0.7 \mathrm{~kg})$. The application injectable drugs in animals presenting clinical symptoms, represented US\$ 0.56/intervention, without difference between the treatments $(\mathrm{P}>0.05)$. Furthermore, independently of the treatment, high frequency of pneumonia was observed (>0.90). No difference for the degree of gastric ulcer nor feces consistency were observed $(\mathrm{P}>0.05)$. The utilization of antibiotic therapy and alternatives to antibiotics in feed did not produce benefits to the production indices and sanitary performances of the animals.
\end{abstract}

Keywords: essential oils; organic acids; prebiotics; probiotics

\section{RESUMO}

A utilização de antimicrobianos na produção animal provoca seleção de bactérias resistentes. $O$ objetivo do estudo foi comparar a utilização de alternativas associadas à antibioticoterapia preventiva na alimentação de suínos nas fases de recria e de terminação. Foram utilizados 1.045 animais de 60 a 190 dias de idade, submetidos a seis tratamentos com 16 repetições, como segue: 1) sem antibióticos; 2) com antibióticos; 3) prebióticos; 4) probióticos; 5) óleos essenciais; e 6) ácidos orgânicos. Os animais foram pesados, e a história clínica foi registrada, incluindo mortalidade e diarreia. No abatedouro, foram investigados índices de pneumonia e úlceras gástricas. $O$ custo de cada tratamento foi discutido. Não houve diferença entre os tratamentos $(P>0,05)$ em relação à taxa de conversão alimentar (2,64 $\pm 0,03)$, ao ganho de peso médio geral (107,06 $\pm 0,9 \mathrm{~kg}$ ), ao ganho de peso médio diário $(856,49 \pm 7,7 \mathrm{~g})$ e ao peso de carcaça $(92,4 \pm 0,7 \mathrm{~kg})$. A aplicação de medicamentos injetáveis em animais com quadro clínico representou US\$0,56/intervenção, sem diferença entre os tratamentos $(P>0,05)$. Além disso, independentemente do tratamento, foi observada alta frequência de pneumonia $(>0,90)$. Não foi observada diferença para o grau de úlcera gástrica nem na consistência das fezes $(P>0,05)$. A utilização de antibioticoterapia e de alternativas aos antibióticos na ração não trouxe benefícios aos desempenhos zootécnico e sanitário dos animais.

Palavras-chave: ácidos orgânicos, óleos essenciais, prebióticos, probióticos

*Corresponding author: vanessa.peripolli@ hotmail.com Submitted: June 10, 2021. Accepted: September 28, 2021. 


\section{INTRODUCTION}

The agricultural sector is responsible for the consumption of roughly $70 \%$ of the antimicrobials produced worldwide, although the animal biomass is bigger than the human, this information demonstrates the need for the sector to adjust to the global call towards reduction of its use in animal and crop productions (Critically..., 2011). The major concern is based in that a routine utilization of antimicrobials in animal production promote the acceleration of the selection process of resistant bacteria, indicating, therefore, a raising concern for human and animal health (Van Boeckel et al., 2015).

The control of the antimicrobial resistance follows guidelines tripartite between World Health Organization (WHO), World Organization for Animal health (OIE) and Food and Agriculture Organization of the United nations (FAO/Codex Alimentarius), which invites the sectors that use antimicrobials to unite in a worldwide campaign to reduce its utilization (Report..., 2018). Furthermore, news and publications about superbacteria raised intense public debates, which was posteriorly recognized by the OMS, that stimulated national policy developers to adhere to support reduction in antibiotic utilization for human and veterinary medicine (Antimicrobial..., 2014).

According to data published by the European Food Safety Agency (EFSA), the European Centre for Disease Prevention and Control (ECDC) and the European Medicines Agency (EMA), the utilization of antibiotics in animals is greater than in humans (Daesieleire et al., 2016). Furthermore, indirectly, other risk factors can impact the antimicrobial resistance in swine, such as area and size of the facilities, the cleaning and disinfection procedures, stage of production, entry of animals and people in the facilities, distance from other buildings as well as frequency, doses and drug administration methods (Burow and Käsbohrer, 2017).

For the goal of reduction of the recurrent utilization of antibiotics, a more intense observation of the production system has to be intensified, in association with increase in the research regarding utilization of alternative additives to the feed (Vardali et al., 2018). These additives can be divided according the mechanism of action, described as follows: 1) Probiotics, which are live cultures of microorganisms that are added to the diet aiming to improve the balance of microbial colonies within the gastrointestinal tract (Lan et al., 2016); 2) Prebiotics, non-digestible ingredients that are used as fermentative substrate and support growth and activity of desirable intestinal bacteria (Di Gioia and Biavati, 2018); 3) Organic acids, which affect directly the intestinal microflora, supporting the growth of beneficial bacteria, improving, as consequence, animal health (Upadhaya et al., 2014); lastly, 4) Essential oils, composts derived from plants, which and have antibacterial effects and support growth (Omonijo et al., 2018).

Under this context, the objective of this study was to evaluate the effect of the complete removal of antibiotics with an in feed antibiotic therapy and prophylactic alternatives using prebiotics, probiotics, essential oils, and organic acids added to the diets on the growing and finishing stages and compare the production indices, economical and sanitary performances of pigs.

\section{MATERIALS AND METHODS}

All the procedures performed in this study were approved by the Animal Care Committee (CEUA) of the Instituto Federal Catarinense Campus Araquari (http://araquari.ifc.edu.br/ceua/) under the protocol number $n^{\circ} 50 / 2017$.

The experiment was performed in commercial swine farm, which was adapted for experimentation, located in Aurora/SC, Brazil $\left(27^{\circ} 23^{\prime} 26.8^{\prime \prime} \mathrm{S}\right.$ e $\left.49^{\circ} 37^{\prime} 13.8^{\prime \prime} \mathrm{O}\right)$, during the period between February and June of 2018. The climate is considered $\mathrm{Cfa}$ (moist mesothermal with hot summer), according to the Koppen classification system.

In the study 1,045 swine were used, with an average starting weight of $22.30 \pm 0.03 \mathrm{~kg}$, from the overall sampling population, 522 were females (Landrace X Large White) and 523 were males (Large White X Pietrain X Duroc X Landrace). The experimental period comprised the growing and finishing stages, from 65 to 195 days, corresponding to a total of 125 days.

One day before starting the experiment, the piglets were weighted, identified with an ear tag, and allocated homogeneously in one of the 6 
treatments, taking also in consideration the sex (male or female) and initial weight. The animals were allocated in two pavilions, each with 48 stalls, 1 stall was kept empty. On the first pavilion 12 animals were allocated per stall, whereas on the second the stalls supported 10 animals. Feed was provided manually, and water was available through pacifier drinkers, both provided ad libitum.

The males were subjected to immune castration (Vivax, Zoetis, EUA) with the first dose applied at 53 days and the second at 88 days.

The isoenergetic and isoproteic diets were formulated to fulfill the nutritional requirements in accordance with the stage of production (Table 1). The only difference was related to the additive used or the absence of it. The treatments were as follows:

T1 - Antibiotic free: Feed without antibiotic or additive.

T2 - With antibiotic: Used during the initial growing stage (provided from $14 \mathrm{~d}$ from 65-79 days of age: Amoxicillin $=400 \mathrm{ppm}$; Lincomycin 180ppm; Ivermectin $=2.4 \mathrm{ppm}$ ); Utilization as support in the growing stage (provided from $14 \mathrm{~d}$ from 100-114 $\mathrm{d}$ : Tilmicosin $=400 \mathrm{ppm} ;$ Colistin $=250 \mathrm{ppm}$; Ivermectin $=2.4 \mathrm{ppm}$ ); Utilization during finishing stage (provided from $14 \mathrm{~d}$ from
129-143 days of age: Amoxicillin=450ppm; Lincomycin $=180 \mathrm{ppm}$ ).

T3 - With prebiotic (mananoligosaccharides MOS) (Actigen, Alltech()): Used during growing stage (provided from $63 \mathrm{~d}$, from $65-128 \mathrm{~d}$ of age: $400 \mathrm{~g} / \mathrm{t}$ ); Used during finishing stage (provided for $62 \mathrm{~d}$ from $129-190$ days of age: $200 \mathrm{~g} / \mathrm{t}$ ).

T4 - With probiotics (Bacillus spp., B. bifidum, E. faecium, L. acidophilus) (DBI, Imeve(C): Used during growing stage (provided from $63 \mathrm{~d}$, from 65-128 d of age:500g/t); Used during finishing stage (provided for $62 \mathrm{~d}$ from 129-190 days of age: $500 \mathrm{~g} / \mathrm{t})$.

T5 - With essential oils (Thymol and Carvacrol) (Dysantic, Vetanco@): Used during growing stage (provided from $63 \mathrm{~d}$, from 65-128 d of age: $1,000 \mathrm{~g} / \mathrm{t}$ ); Used during finishing stage (provided for $62 \mathrm{~d}$ from 129-190 days of age: $1,000 \mathrm{~g} / \mathrm{t})$.

T6 - With organic acids (lactic, citric, and ascorbic acid) (Acidufeed, Quinabra@): Used during growing stage (provided from $63 \mathrm{~d}$, from 65-128 d of age: $1,000 \mathrm{~g} / \mathrm{t}$ ); Used during finishing stage (provided for $62 \mathrm{~d}$ from 129-190 days of age: $500 \mathrm{~g} / \mathrm{t})$.

The inclusion of the treatment in the feed was performed during the formulation of the diets. Between the processing of the different diets, a cleaning was performed in the production line using crushed corn.

Table 1. Nutritional composition for basal diets offered to the animals during the experimental period

\begin{tabular}{lllll}
\hline Diet stage & Age after housing $(\mathrm{d})$ & $\begin{array}{l}\text { Kcal } \\
\text { EM/kg }\end{array}$ & $\begin{array}{l}\text { Digestive } \\
\%\end{array}$ & $\begin{array}{l}\text { lysine, } \\
\text { Phosphorus, } \\
(\%)\end{array}$ \\
\hline Growing (piglets) & $0-14$ & 3,450 & 1.100 & 0.400 \\
Growing 1 & $15-35$ & 3,375 & 1.050 & 0.350 \\
Growing (Support) & $36-49$ & 3,350 & 1.000 & 0.350 \\
Growing 2 & $50-63$ & 3,350 & 0.950 & 0.350 \\
Finishing 1 & $64-77$ & 3,360 & 0.890 & 0.300 \\
Finishing 2 Male & $78-125$ & 3,380 & 0.750 & 0.300 \\
Finishing 2 Female & $78-125$ & 3,400 & 0.850 & 0.300 \\
\hline
\end{tabular}

On the farm, each treatment was stored in a silo. The feed offered and the residual feed from each stall was weighted daily to calculate the feed conversion rate (FCR) per stall. The animals were weighted individually at the transition of each feed change, to calculate individual weight gain (WG), average weight gain $(\mathrm{kg})$ and average daily gain (ADG).
The feces consistency score was evaluated through subjective evaluation of each stall in a weekly basis, during the whole experimental period. The samples observed were classified in normal, soft, or liquid.

The experiment lasted 125 days, after which the animals were send to a slaughterhouse with a Federal Inspection System (SIF1156). After 
evisceration, 176 gastrointestinal tracts and lungs were collected in the federal inspection line, the samples were individually stored in individual plastic bags, properly identified, and stored for posterior evaluation.

The lungs were evaluated following a methodology described by Sobestiansky et al. (2012). In each pulmonary lobe evaluated, a percentage corresponding to the area impacted was attributed to the lesions. The macroscopic lesions of pulmonary consolidation were classified according to the affected area, as well as presence of abscesses areas of adherence to the visceral pleura. The model for classification of lesions on the parenchyma was performed as described by Piffer and Brito (1991), and the classifications were: Right - Apex; Cardiac and Diagrammatic; and Left - Apex; Cardiac and Diagrammatic; and Intermediary. To evaluated the values for the pneumonia index (PI), the values obtained were grouped and classified from $0.0-0.55$ : low index of pneumonia; 0.56-0.89: Indicative of pneumonia with low risk to the herd; $>0.90$ : high frequency of pneumonia in the herd (Piffer and Brito 1991; Dalla Costa et al., 2000; Sobestiansky et al., 2012; Morés et al., 2013).

The evaluation of the gastric mucosa was performed through an incision via the major curvature, after cleaning with water, a visual inspection was performed to determine the degree of the ulcers present in the stomach. The score of the lesion was classified from 0-4 based on the macroscopic characteristics. Lastly the Pars oesophagea was evaluated as described by Sobestiansky et al. (2012).

The cost of the diets was evaluated including the proportion of increase in price due to the inclusions of antibiotics or additives in comparison with feed without additives. A total consumption of $280 \mathrm{~kg}$ was considered per animal during the experimental period.

The animals with clinical symptoms during the experimental period were identified and subjected to medical treatment with injectable drugs, in accordance with the orientation by the veterinary responsible. Each of those animals were identified and the following data were recorded: date, ear tag number, sex, supposed diagnostic, treatment group, active principle of the drug used, drug administration method and duration of treatment.

The data were analyzed through the software Statistical Analysis System (SAS®, Inst. Inc., Cary, NC, v.9.3). The experimental design followed the utilization of random blocks (housing pavilions), with six treatments (experimental feeds) and 16 repetitions (stalls). Each stall was considered an experimental unit for the variables of feed consumption, feed conversion rate and feces consistency score. Each single animal was considered an experimental unit for the variables of average weight gain, PI and gastric ulcer. The continuous variables were analyzed through the MIXED method with comparison of the means through the TukeyKramer test. The categorical variables were analyzed through the GLIMMIX model. The results were described as Mean \pm Standard Error of the Mean or percentage, in accordance with each variable. Statistical significance was considered for $\mathrm{P}<0.05$.

\section{RESULTS}

No difference $(\mathrm{P}>0.05)$ was observed between the treatments for feed conversion rate $(\mathrm{P}=0.2887)$ and average weight gain $(\mathrm{P}=0.3535)$ (Table 2$)$. The average weight gain was $107.06 \pm 0.9 \mathrm{~kg}$, with a daily weight gain averaging $856.49 \pm 7.7 \mathrm{~g}$ and average carcass weight of $92.4 \pm 0.7 \mathrm{~kg}$. Throughout the 125 days of experimentation, 18 animals were deceased $(1.72 \%)$.

The average feed consumption did not differ between the treatments $(\mathrm{P}=0.1536$, Table 3$)$. The increase of the feed cost in comparison to the treatments without inclusion of antibiotics or alternative additives varied from 0.62 to $2.83 \%$ (Table 3).

The need of injectable medication in animals with clinical symptoms represented an average of US\$ 0.56 /intervention, without difference between the groups ( $\mathrm{P}>0.05$, Table 4$)$.

All treatments presented a high index $(>90 \%)$ for the pneumonia index (PI) $(\mathrm{P}>0.05)$. Furthermore, all groups presented similar degrees of gastric ulcer and feces consistency score $(\mathrm{P}>0.05$, Table 5). 
Effects of in feed...

Table 2. Feed conversion rate (FCR), deceased animals (n) and average weight (Kg) gain (AWG) of pigs during the growing and finishing stages according to the treatment

\begin{tabular}{llllll}
\hline Treatment & Stalls & $\begin{array}{l}\text { Animals } \\
(\mathrm{n})\end{array}$ & $\begin{array}{l}\text { FCR } \\
(\text { Mean } \pm \text { SEM) }\end{array}$ & $\begin{array}{l}\text { Mortality } \\
\text { rate }\end{array}$ & $\begin{array}{l}\text { AWG (Kg) } \\
\text { (Mean } \pm \text { SEM) }\end{array}$ \\
\hline T1 Antibiotic free & 12 & 173 & $2.63 \pm 0.03$ & $4 / 173$ & $107.49 \pm 0.97$ \\
T2 Antibiotic & 13 & 184 & $2.64 \pm 0.03$ & $4 / 184$ & $106.51 \pm 0.94$ \\
T3 Prebiotic & 12 & 174 & $2.64 \pm 0.03$ & $2 / 174$ & $108.36 \pm 0.96$ \\
T4 Probiotic & 11 & 164 & $2.63 \pm 0.03$ & $5 / 164$ & $105.96 \pm 1.01$ \\
T5 Essential oils & 12 & 176 & $2.70 \pm 0.03$ & $3 / 176$ & $105.74 \pm 0.96$ \\
T6 Organic acids & 12 & 174 & $2.63 \pm 0.03$ & $0 / 174$ & $107.52 \pm 0.96$ \\
Pr>F & & & 0.2887 & & 0.3535 \\
\hline
\end{tabular}

Pr>F: Probability; n: number of animals; SEM: Standard error of the mean.

Table 3. Average consumption (kg) (AC) and average feed cost (280kg)/animal (ACF) (U\$) of pigs during the growing and finishing stages according to the treatment

\begin{tabular}{|c|c|c|c|c|c|}
\hline Treatment & Stalls & $\begin{array}{l}\mathrm{AC}(\mathrm{kg}) \\
(\mathrm{Mean} \pm \mathrm{SEM})\end{array}$ & $\begin{array}{l}\text { ACF } \\
\text { US\$ }\end{array}$ & $(280 \mathrm{~kg})$ & $\begin{array}{l}\text { Difference } \\
\text { T1, US\$ }(\%)\end{array}$ \\
\hline T1 Antibiotic free & 12 & $282.30 \pm 2.08$ & 56.31 & & $0.00(100.00)$ \\
\hline T2 Antibiotic & 13 & $280.70 \pm 2.05$ & 58.35 & & $2.05(103.63)$ \\
\hline T3 Prebiotic & 12 & $285.88 \pm 2.08$ & 56.66 & & $0.35(100.62)$ \\
\hline T4 Probiotic & 11 & $278.73 \pm 2.14$ & 56.83 & & $0.52(100.92)$ \\
\hline T5 Essential oils & 12 & $278.53 \pm 2.08$ & 59.13 & & $2.83(105.02)$ \\
\hline T6 Organic acids & 12 & $281.86 \pm 2.082$ & 57.57 & & $1.27(102.25)$ \\
\hline $\operatorname{Pr}>\mathrm{F}$ & & 0.1536 & & & \\
\hline
\end{tabular}

Pr>F: Probability; n: number of animals; SEM: Standard error of the mean.

Table 4. Interventions with injectable medication in pigs with clinical symptoms of disease during growing and finishing stages according to the treatment

\begin{tabular}{lllll}
\hline Treatment & Animals (n) & $\begin{array}{l}\text { Treated animals } \\
(\mathrm{n}, \%)\end{array}$ & $\begin{array}{l}\text { Total } \\
\text { interventions (n) }\end{array}$ & $\begin{array}{l}\text { Average cost } \\
\text { per intervention } \\
\text { Mean } \pm \text { SEM }\end{array}$ \\
\hline T1 Antibiotic free & 173 & $94(54.33)$ & 211 & $0.50 \pm 0.03$ \\
T2 Antibiotic & 184 & $94(51.09)$ & 184 & $0.57 \pm 0.06$ \\
T3 Prebiotic & 174 & $92(52.87)$ & 212 & $0.52 \pm 0.03$ \\
T4 Probiotic & 164 & $106(64.63)$ & 234 & $0.49 \pm 0.02$ \\
T5 Essential oils & 176 & $77(43.75)$ & 128 & $0.67 \pm 0.10$ \\
T6 Organic acids & 174 & $88(50.57)$ & 174 & $0.49 \pm 0.03$ \\
Pr>F & & & 0.4597 \\
\hline Pr & & & \\
\hline
\end{tabular}

Pr>F: Probability; n: number of animals; SEM: Standard error of the mean.

Table 5. Pneumonia index (PI), gastric ulcer and feces consistency score in pigs during the growing and finishing stages according to the treatment

\begin{tabular}{|c|c|c|c|c|c|c|c|c|}
\hline \multirow[t]{3}{*}{ Treatment } & \multirow[t]{3}{*}{$\mathrm{PI}^{1}$} & \multicolumn{4}{|c|}{ Gastric ulcer $^{2}$} & \multirow{2}{*}{\multicolumn{3}{|c|}{ Feces consistency score ${ }^{3}, \%(n)$}} \\
\hline & & \multirow{2}{*}{$\begin{array}{l}\text { Absence } \\
(\mathrm{n}=131)\end{array}$} & \multicolumn{3}{|c|}{ Presence $(n=45), \%(n)$} & & & \\
\hline & & & Degree1 & Degree2 & Degree3 & Normal & Soft & Liquid \\
\hline T1 Antibiotic free & 1.03704 & 21 & $6.67(3)$ & $2.22(1)$ & $4.44(2)$ & $10.85(177)$ & $3.68(60)$ & $1.10(18)$ \\
\hline T2 Antibiotic & 1.12500 & 26 & $6.67(3)$ & $2.22(1)$ & $4.44(2)$ & $12.99(212)$ & $3.00(49)$ & $0.67(11)$ \\
\hline T3 Prebiotic & 0.96667 & 22 & $11.11(5)$ & $4.44(2)$ & $0.00(0)$ & $11.03(180)$ & $3.37(55)$ & $1.23(20)$ \\
\hline T4 Probiotic & 0.93103 & 22 & $15.56(7)$ & $0.00(0)$ & $2.22(1)$ & $11.34(185)$ & $4.11(67)$ & $1.23(20)$ \\
\hline T5 Essential oils & 0.96667 & 19 & $8.89(4)$ & $8.89(4)$ & $6.67(3)$ & $11.70(191)$ & $5.02(82)$ & $0.98(16)$ \\
\hline T6 Organic acids & 1.00000 & 21 & $8.89(4)$ & $2.22(1)$ & $4.44(2)$ & $12.32(201)$ & $4.35(71)$ & $1.04(17)$ \\
\hline
\end{tabular}

${ }^{1} 176$ animals sampled; ${ }^{2} 176$ animals sampled, Pr>F: $0.5536 ;{ }^{3}$ a weekly evaluation in each stall, in a total of 1,632 observations during the experimental period, Pr $>\mathrm{F}: 0.1481$; n: number of animals. 


\section{DISCUSSION}

The major finding observed in our study is that the total removal of antibiotic in feed was not different from the other groups when production indices and health indicators were compared, indicating, therefore, that antibiotics in feed may not be needed for a profitable and successful production system, corroborating with a previous study (Diana et al., 2017). Therefore, it's possible to infer that the removal of antibiotics from the feed provided to the pigs during the growing and finishing stages, however a more restrict control needs to be employed towards possible risk factors for diseases and ambience where the animals will be raised (Gómez-García et al., 2019).

The production model that uses antimicrobials in a large scale raises worldwide concerns (Hoelzer et al., 2018). Animal protein producers Countries are stablishing policies for a rational utilization of antimicrobials, therefore, the identification of alternatives to reduce the antimicrobial utilization is necessary (Garcia et al., 2019). Studies investigating the impacts of the removal of antimicrobial utilization in the animal production system will be the core of the urgent changes required in this scenery where paradigms are being challenged.

Although we obtained very promising results in our study, the literature is yet inconclusive regarding the possibilities of utilization of alternative additives aiming to reduce or even substitute the use of antimicrobials in feed (Viana Ferreira et al., 2017).

Among the studied products, probiotics, prebiotics, organic acids and phytotherapics have been described previously (Upadhaya et al., 2014; Viana Ferreira et al., 2017; di Gioia and Biavati, 2018; Rahimi, 2019).

The prebiotics function as a fermentation substrate, stimulating positively the beneficial bacteria from the gastrointestinal tract (di Dioia and Biavati, 2018). Similar to our results Edwards et al. (2014), using Actigen TM (Alltech ${ }^{\circledR}$ Inc., EUA), have not observed differences in pigs' growth performance during the finishing phase, however, a positive effect on carcass yield was found. In comparison with cooper and tylosin (Beer et al., 2015), the same bioactive compound did not impact the growing and finishing stages or improve the carcass quality of pigs.

Probiotics are live organisms, which selectively compete with pathological/undesirable microbes (Liu et al., 2017). The probiotics used in studies with pigs are quite variable and presented a broad response when used in different conditions, and therefore, age, diet, ambient and handling method should be considered for the selection of the probiotic to be used (Barba-Vidal et al., 2019). The utilization of a commercial mixture consisting of $0.02 \%$ Bacillus spp and Clostridium butyricum on the diet, increased body weight at week $12(88.9 \pm 0.4 \mathrm{~kg})$ and week 16 $(113.2 \pm 0.7 \mathrm{~kg})$, as well as average daily gain (ADG) $(802.0 \pm 6.5 \mathrm{~g})$ and decreased diarrhea caused by Escherichia coli $\left(7.5 \pm 0.02 \quad \log _{10}\right.$ $\mathrm{CFU} / \mathrm{g}$ ) in pigs during the growing and finishing stages (Balasubramanian et al., 2018). Furthermore, different from our study, the utilization of Lactobacillus spp, Bifidubacterium lactis and Streptococcus termophilus in the diet improved the feed conversion rate of pigs during the growing and finishing stages (Tufarelli et al., 2017). Interestingly, in another study, although the utilization of Bacillus spp. improved feed conversion rate in pigs during growing stage $(\mathrm{P}<0.05)$ (Jorgensen et al., 2016), a significant impairment on the parameter was observed during finishing (Giang et al., 2011).

There are several options for organic acids and commercial mixes. A blend of caproic, caprylic, fumaric, citric and malic acids was used in a previous study in a concentration of $0.2 \%$ improving the average daily weight gain $(\mathrm{P}<0.05)$ from 0 to 6 weeks $(820.0 \pm 7.0 \mathrm{~g})$ and from 6 to 12 weeks $(879.0 \pm 13.0 \mathrm{~g})$, reducing pathogenic bacteria during 12 weeks $\left(5.9 \pm 0.1 \log _{10} \mathrm{CFU} / \mathrm{g}\right)$ in the finishing stage (Upadhaya et al., 2014) and improving the growth phase $(745.0 \pm 9.0 \mathrm{~g})$ supporting the increase of the healthy microbiota Lactobacillus $\left(7.5 \pm 0.04 \log _{10} \mathrm{CFU} / \mathrm{g}\right)$ in the same interval (Upadhaya et al., 2015).

Another inclusion used in feed are the organic acids and essential oils. The inclusion of formic and citric acids as well as oils derived from citric fruits, cinnamon, oregano and thyme, caused reduction in Salmonella, being $64.5 \%$ for the treatment group compared to $88.5 \%$ for the control group $(\mathrm{P}=0.01)$, without changing the performance in the finishing phase $(\mathrm{P}>0.05)$, 
although, the additive cost caused an increase in the feed price (Walia et al., 2017).

On the other hand, when considering the economical aspect of the production system, the non-utilization of antibiotics, even when compared to the utilization of prophylactic additives, is an interesting alternative. Feed comprehends roughly $70 \%$ of the total cost in swine production (Pomar and Remus, 2019), therefore, the identification of possibilities that improve the cost-benefit of the system are fundamental to keep it profitable (Walia et al., 2017). In this study, the average cost with the utilization of antibiotics in the sanitary plans throughout the pre-stablished stages during growing and finishing was US\$2.05/animal. However, it did not determine any improvement on performance.

Besides the costs with the treatments in feed, the number of medical interventions was taken in consideration, with the consequential increase in the economical return of the treatments. The utilization of the treatments in animals with clinical symptoms costed in average US\$0.56/intervention, without difference $(\mathrm{P}>0.05)$ between the treatments. It is important to indicate that the parenteral application of antibiotic was permitted, guaranteeing an approach more oriented and limited.

The PI was considered high (>90\%) (Sobestiansky et al., 2012) and no difference was observed between the treatments $(\mathrm{P}>0.05)$. The high PI indicates a great probability in the occurrence of pneumonia with the presence of several risk factors. During the experiment, the clinical investigation and application of medical treatments was prompt and agile, however, situations such as mixing litters from different sources, may increase the cases and spread of a contagious disease.

Furthermore, besides the IP, the index for gastric ulcers and feces consistency score did not present differences between the groups $(\mathrm{P}>0.05)$. Interestingly, the utilization of organic acids as an acidifier of the feed, did not cause changes in the production performance of the animals nor caused modifications in the nutrient digestibility, lastly, no diarrhea cases were observed (Boas et al., 2016). In another study, it was demonstrated that the substitution in feed to probiotics and prebiotics improved the performance and nutrient digestibility in piglets in the nursery stage (Amphonephet et al., 2018).

The piglets used in this experiment were from different farms from distinct regions of the state of Santa Catarina (Brazil) and spent the nursery stage in a unit considered under a high risk of infection due to the mixing of animals from different sources. Therefore, the animal production indices of the present study are within the expected for pigs during the growing and finishing stages. Besides considering the inclusion of alternative additives to the feed, we must consider other factors such as handling (ambience), immunization (efficient immunization programs) and good nutritional program (Smits et al., 2017).

Nowadays, the swine production models in Brazil have several environment factors impacting the balance and the infection pressure as well as the capacity of the animals to overcome the sanitary barrier, developing symptoms or not, which would impact on the severity of the case (Smits et al., 2017), and consequently, influence the performance of the animals. Factors such as low temperatures, ventilation, high populational density, mixing litters from different origins and ages, are crucial risk factors that must be controlled to avoid risk of disease within the herd.

A thorough review on the topic (Postma et al., 2017) described a list with 19 items considered as alternatives for the antimicrobial use in the swine production system. Another study tested the possibility of total removal of antimicrobials in feed (Móres et al., 2013), using 3 basic procedures for disease prevention in the herd: 1) Not mixing litters from birth to slaughter; 2) Reduction in animal density in the whole production system as well as providing more space for the animals from weaning to slaughter; 3) Utilization of diets formulated with high digestible ingredients, reducing the risk of developing enteral problems.

The concern above indicated comes in context with recent discussion involving basic handling procedures and their possible impact on the internal and external biosecurity in the farms, from avoiding the infiltration of new pathogens as well as reduced the impact of the diseases already present. Alternatives to substitute or reduce the utilization of antibiotics in feed require effort and 
time, however, the data indicated above support the viability of such affirmation and indicate that it can be used in the field without impacting production indices and health of the animals, as observed in the present study.

Therefore, the new challenge is related to expansion of the studies involving the removal of antibiotics or its substitution for additives in the routine of the farms where the challenges are more intense as well as the implementation of the idea in the different stages of the production system, e.g. the nursery, where the mixing of litters and high animal density are usual factors.

Lastly, although the challenge to produce healthy food remains the same, the companies involved with animal production need to overcome the challenge of a new production system with the rational utilization of antimicrobials or even with their total absence. Therefore, a radical change is required in the perspectives of the productive chain as well as improving and training workers, disease control, adequate utilization of vaccines, preventive and curative medicine, improvement in nutrition, ambience, and biosecurity programs in the animal production units.

\section{CONCLUSION}

The removal of antibiotic in feed and utilization of non-antibiotic treatments was successful, since it produced similar results to treatment containing antibiotics. Furthermore, it kept the same level of sanitary and production indices of pigs during the growing and finishing stages when compared to animals that received antibiotics. Therefore, the study concludes towards the success of the removal of prophylactic antibiotics in feed and possible utilization of alternative additives, which can be considered as a possible perspective for the swine production, since it maintained similar results as animals treated with antibiotics in feed without any notable impairment on productive performance or health.

\section{ACKNOWLEDGEMENTS}

PAMPLONA Alimentos SA; Embrapa Suínos e Aves; Conselho Nacional de Desenvolvimento Científico e Tecnológico (CNPq; Coordenação de Aperfeiçoamento de Pessoal de Nível Superior (CAPES).

\section{REFERENCES}

AMPHONEPHET, S.; TUMWASORN, S.; POEIKHAMPA, T.; LOONGYAI, W. Effect of supplementation of probiotic and beta-glucan to antibiotic-free diets on. Scholar J. Appl. Sci. Res., v.1, p.37-42, 2018.

ANTIMICROBIAL resistance global report on surveillance. [Geneva]: WHO, 2014. 1p. Available in: https://www.who.int/drugresistance/documents/s uerveillancereport/en/. Acessed in: 10 Dec. 2020.

BALASUBRAMANIAN，B.; LEE，S.I.; KIM, I.H. Inclusion of dietary multi-species probiotic on growth performance, nutrient digestibility, meat quality traits, faecal microbiota and diarrhoea score in growing-finishing pigs. Ital. J. Anim. Sci., v.17, p.100-106, 2018.

BARBA-VIDA, E; MARTÍN-ORÚE, S.M.; CASTILLEJOS, L. Practical aspects of the use of probiotics in pig production: A review. Livest. Sci., v.223, p.84-96, 2019.

BEER, S.L.; COLLINS, C.L.; HENMAN, D.J.; NAYLOR, A. Maintaining finisher pig performance without dietary organic cooper with a mannan-rich fraction of Saccharomyces cerevisiae. Anim. Prod. Sci., v.55, p.1557-1557, 2015.

BOAS, A.D.C.V.; BUDIÑO, F.E.L.; NETO, M.A.T. et al. Organic acids in diets of weaned piglets: Performance, digestibility and economical viability. Arq. Bras. Med. Vet. Zootec., v.68, p.1015-1022, 2016.

BUROW, E.; KÄSBOHRER, A. Risk factors for antimicrobial resistance in escherichia coli in pigs receiving oral antimicrobial treatment: a systematic review. Microbiol. Drug. Resist., v.23, p.194-205, 2017.

CRITICALLY important antimicrobials for human medicine. 3.ed. rev. Switzerland: AGISAR, 2011. 52p.

DAESELEIRE, E.; GRAEF, E.; RASSCHAERT, G. et al. Antibiotic use and resistance in animals: Belgian initiatives. Drug. Test. Anal., v.8, p.549$555,2016$. 
DALLA COSTA, O.A.; MORES, N.; SOBESTIANSKI, J. et al. Fatores de risco associados a rinite atrófica progressiva nas fases de crescimento e terminação. Concórdia: Embrapa Suínos e Aves, 2000. (Comunicado técnico). 5p.

DI GIOIA, D.; BIAVATI, B. Probiotics and prebiotics in animal health and food safety: conclusive remarks and future perspectives. [Heidelberg]: Springer, 2018. p.269-273.

DIANA, A.; MANZANILLA, E.G.; CALDERÓN DÍAZ, J.A. et al. Do weaner pigs need in-feed antibiotics to ensure good health and welfare? PLoS ONE, v.12, p.1-15, 2017.

EDWARDS, M.V.; EDWARDS, A.C.; MILLARD, P.; KOCHER, A. Mannose rich fraction of Saccharomyces cerevisiae promotes growth and enhances carcass yield in commercially housed grower-finisher. Anim. Feed Sci. Technol., v.197, p.227-232, 2014.

GARCIA, G.R.; DOGI, C.A.; POLONI, V.L. et al. Beneficial effects of saccharomyces cerevisiae RC016 in weaned piglets: In vivo and ex vivo analysis. Benef. Microbes., v.10, p.33-42, 2019.

GIANG, H.; VIET, T.T.; OGLE, B.; LINDBERG, J.E. Effects of supplementation of probiotics on the performance, nutrient digestibility and faecal microflora in growing-finishing pigs. Asian Australas. J. Anim. Sci., v.24, p.665-661, 2011.

GÓMEZ-GARCÍA, M.; SOL, C.; DE NOVA, P.J.G. et al. Antimicrobial activity of a selection of organic acids, their salts and essential oils against swine enteropathogenic bacteria. Porcine Health Manag., v.5, p.1-8, 2019.

HOELZER, K.; BIELKE, L.; BLAKE, D.P. et al. Vaccines as alternatives to antibiotics for food producing animals. Part 1: Challenges and needs. Vet. Res., v.49, p.1-10, 2018.

JORGENSEN, J.N.; LAGUNA, J.S.; MILLÁN, C. et al. Effects of a Bacillus-based probiotic and dietary energy content on the performance and nutrient digestibility of wean to finish pigs. Anim. Feed Sci. Technol., v.221, p.54-61, 2016.

LAN, R.X.; KOO, J.M.; KIM, I.H. Effects of Lactobacillus acidophilus supplementation in different energy and nutrient density diets on growth performance, nutrient digestibility, blood characteristics, fecal microbiota shedding, and fecal noxious gas emission in weaning pigs. Anim. Feed Sci.Technol., v.219, p.181-188, 2016.

LIU, C.; ZHU, Q.; CHANG, J. et al. Effects of Lactobacillus casei and Enterococcus faecalis on growth performance, immune function and gut microbiota of suckling piglets. Arch. Anim. Nutr., v.71, p.120-133, 2017.

MORÉS, N.; AMARAL, A.L.; LIMA, G.J.M.M. et al. Produção de suínos em família, sem uso preventivo de antimicrobiano e privilegiando o bem-estar animal. Concórdia: Embrapa Suínos e Aves, 2013, 114p.

OMONIJO, F.A.; NI, L.; GONG, J. et al. Essential oils as alternatives to antibiotics in swine production. Anim. Nutr., v.4, p.126-136, 2018.

PIFFER, I.A.; BRITO, J.R.F. Descrição de um modelo para avaliação e quantificação de lesões pulmonares de suínos e formulação de um índice para classificação de rebanhos. Concórdia: Embrapa Suínos e Aves Suínos e Aves, 1991. 12p. (Documentos, n.23)

POMAR, C.; REMUS, A. Precision pig feeding: a breakthrough toward sustainability. Anim. Front., v.9, p.52-59, 2019.

POSTMA, M.; VANDERHAEGHEN, W.; SARRAZIN, S.; MAES, D.; DEWULF, J. Reducing antimicrobial usage in pig production without jeopardizing production parameters. Zoonoses Public Healthy, v.64, p.63-74, 2017.

RAHIMI, S. Urgent action on antimicrobial resistance. Lancet. Respir. Med., v.7, p.208-209, 2019.

REPORT on surveillance of antibiotic consumiption. Switzerland: WHO 128p. 2018. Available in: https://www.who.int/medicines/areas/rational_us e/oms-amr-amc-report-2016-2018/en/. Accessed in: Dic. 2020.

SMITS, C.; HEES, V.H.; FERGUSON, N.S. Dietary strategies do maintain enteric health in antibiotic free production. J. Swine Health Prod., v.25, 2017.

SOBESTIANSKY, J.; BARCELLOS, D.; DRIEMEIER, D.; MATOS, M.P.C. Doenças dos suínos. Goiânia: Cânone, 2012. p.915-921. 
TUFARELLI, V.; CROVACE, A.M.; ROSSI, G.; LAUDADIO, V. Effect of a dietary probiotic blend on performance, blood characteristics, meat quality and faecal microbial shedding in growingfinishing pigs. South Afr. J. Anim. Sci., v.47, p.875-882, 2017.

UPADHAYA, S.D.; LEE, K.Y.; KIM, I.H. Effect of protected organic acid blends on growth performance, nutrient digestibility and faecal micro flora in growing pigs. J. Appl. Anim. Res., v.44, p.238-242, 2015.

UPADHAYA, S.D.; LEE, K.; YONG, K.I.H. Protected organic acid blends as an alternative to antibiotics in finishing pigs. Asian Australas. J. Anim. Sci., v.27, p.1600-1607, 2014.

VAN BOECKEL, T.P.; BROWER, C.; GILBERT, M. et al. Global trends in antimicrobial use in food animals. Proc. Natl. Acad. Sci. USA, v.112, p.5649-5654, 2015.
VARDALI, S.C.; SAMANIDOU, V.F.; KOTZAMANIS, Y.P. Development and validation of an ultra performance liquid chromatography-quadrupole time of flight-mass spectrometry (in MSE mode) method for the quantitative determination of 20 antimicrobial residues in edible muscle tissue of European sea bass. J. Chromatogr. A., v.1575, p.40-48, 2018.

VIANA FERREIRA, S.; BARBOSA, L.M.R.; SOARES, M.H. et al. Alternatives to antibiotics in diets of weaned piglets. Cienc. Rural, v.47, p.17, 2017

WALIA, K.; LYNCH, H.; LAWLOR, P.G.; GRANT, J. et al. Effect of strategic administration of an encapsulated blend of formic acid, citric acid, and essential oils on Salmonella carriage, seroprevalence, and growth of finishing pigs. Prev. Vet. Med., v.137, p.28-35, 2017. 